\title{
Asymptomatic bacteriuria amongst menopausal women in calabar, Nigeria
}

\author{
Paul Columba Inyang-Etoh', Abasiodiong Udom Akpan², Victor Udo Usanga ${ }^{3}$, \\ Gabriel Chuks Ejezie ${ }^{4}$
}

${ }^{1}$ Associate Professor, ${ }^{2}$ Medical Laboratory Scientist, ${ }^{4}$ Emeritus Professor, Department of Medical Laboratory Science (Microbiology and Parasitology), Faculty of Allied Medical Sciences, College of Medical Sciences, University of Calabar, Calabar, Nigeria, ${ }^{3}$ Lecturer 1, Department of Medical Laboratory Science (Microbiology and Parasitology), Faculty of Health Sciences, Ebonyi State University,Abakaliki, Nigeria

Background: Bacteriuria is considered a common bacterial infection in women particularly in postmenopausal women whichconsequently maywarrant the need to treat the disease for prevention of bacteriuria developing complications. Aims and Objectives: This work was to investigate the prevalence of asymptomatic bacteriuria among menopausal women in Calabar, the incriminating bacterial pathogens and their antibiotic susceptibility pattern. Materials and Methods: Early morning mid-stream urine samples from randomly selected 200 women (comprising of 50 premenopausal, 50 menopausal, 50 postmenopausal women and 50 apparently healthy young ladies of menstruating age (control subjects)) between the ages of 50 to 90 years were cultured by Leigh and Williams's method. Questionnaires were also administered. Results:24 (16\%) of the test group while $3(6 \%)$ of the control group had infection $(p=0.008)$. Subjects aged $35-40$ years had the highest prevalence of infection $6(18.5 \%)$, while age group $66-70 y r s$ had the lowest infection rate $0(0 \%)(P=0.841)$. Post-menopausal women had the highest prevalence of asymptomatic bacteriuria $10(20 \%)$ while pre-menopausal and menopausal women had a lower prevalence rate of $7(14 \%)$ each $(p=0.0687)$. The most frequently isolated organism was Staphylococcus aureus $(33 \%)$ and Ciprofloxacin was the most sensitive antibiotic observed. Conclusion: This work has revealed a high prevalence rate of asymptomatic bacteriuriahigh level of asymptomatic bacteriuria among menopausal women and the need for routine screening of this category of women for a standard healthy living.

Key words: Asymptomatic bacteriuria; Menopausal women; Calabar

\section{INTRODUCTION}

Asymptomatic bacteriuria is generally a common benign, transient and recurring disease condition among the elderly.The incidence of the disease increases from 3.5\% in the general population to between $16 \%$ and $18 \%$ in women. ${ }^{1}$ Bacteriuria is among the most common infectious diseases in women especially young and sexually active women, and in postmenopausal women. ${ }^{2}$ The disease has also been reported to present in a somewhat different way among postmenopausal older women than it is in younger women. ${ }^{3}$ Estrogen deficiency probably explains the higher rates in menopausal women. ${ }^{1}$ Due to high prevalence of asymptomatic bacteriuria among elderly women, an exacerbation of multiple co-morbidities can lead to urinary symptoms likeurgency, frequency, and dysuria. ${ }^{1}$ Chronic urinary incontinence can make it difficult to differentiate asymptomatic bacteriuria (which is benign) from symptomatic bacteriuria (which has the potential to evoke urosepsis or pyelonephritis). ${ }^{1}$ Several studies have reported high prevalence of asymptomatic bacteriuria among women consequently there is always the need to treat asymptomatic bacteriuria for prevention of UTI developing complications. ${ }^{4,5}$ Also a number of studies

Address for Correspondence:

Dr P. C. Inyang-Etoh, Medical Laboratory Science Department, Faculty of Allied Medical Sciences, College of Medical Sciences,

University of Calabar, P. M. B. 1115, Calabar, Cross River State, Nigeria. Phone: +2348037237567.

E-mail: inyangetoh@yahoo.com 
have shown that antimicrobial treatment in asymptomatic bacteriuria does not really lead to decrease in the frequency of recurrences and re-infections. Therefore there is a current opinion in the literature that prescription of antibiotics in asymptomatic bacteriuria makes sense only in the case of additional factors of UTI development, such as a need for catheterization and urinary tract structural anomalies.A fundamentally approach to prevent recurrent UTI in postmenopausal women is an estrogen regimen,other strategies include the restoration of flora with lactobacilli using probiotics and another is the use of cranberry. ${ }^{6}$ This work was to establish the current prevalence of asymptomatic bacteriuria among menopausal women patients in Calabar, and the incriminating bacterial pathogens and their antibiotic susceptibility pattern.

\section{MATERIALS AND METHODS}

\section{Study area}

This study was carried out between May and December, 2017 in Calabar, the capital city of Cross River State, Nigeria. Calabar has a population of 371,022 according to 2006 census. ${ }^{7}$ The University of Calabar Teaching Hospital (UCTH) and the General Hospital (GH), Calabar provide tertiary and secondary health care needs of the people living in the state. However there are about eighteen (18) private clinics that provide supportive health care to patients. The city is within the rain forest belt of Nigeria two seasons; the dry season and rainy season. The region has a rainy season from April until October, and dry season from November to March. It has a relative humidity between $80 \%$ and $100 \%$ during rainy season. Average temperature ranges from $24^{\circ} \mathrm{C}$ $\left(75^{\circ} \mathrm{F}\right)$ on August to $30^{\circ} \mathrm{C}\left(86^{\circ} \mathrm{F}\right)$ in February. Residents are mostly civil servants, trader of various cadres, famers and artisan. It's inhabited by different tribes; the Efiks, Ibibios, Annangs, Igbos, Hausas, Yorubas, Cameroonians and others.

\section{Subjects}

This was a cross sectional study of 200 women (comprising of 50 premenopausal, 50 menopausal, 50 postmenopausal women and 50 apparently healthy young ladies of menstruating age (control subjects)) who live in both South and North of Calabar metropolis. Subjects were recruited based on simple random sampling method.

\section{Study design}

The under listed sequence of activities were followed

- Seeking and obtaining of Ethical approval.

- Inform consent from the subjects which explains the detail procedure of the study

- Questionnaire administration.

- Collection and processing of clean catch mid-stream urine specimens.

\section{Ethical consideration}

Ethical clearance was sought and obtained from Ethical committee of University of Calabar Teaching Hospital (UCTH), Calabar. Informed consent in the form of a signed consent was sought and obtained from the patients or other relation in situation where the patient cannot sign the consent form.

\section{Questionnaire administration}

Questionnaires were also administered on each of the subjects for the following information; Previous history of UTI, antibiotic usage, marital status, age, status of menopause, history of urosepsis or pyelonephritis, history of Parkinson disease, cerebrovascular disease, diabetics, catheter, hypertension, occupation etc to help in the research process.

\section{Exclusion criteria}

Subjects who reported signs and symptoms of UTI like dysuria, incontinence, frequency, urgency, suprapubic pain or flank pain were excluded from the research.

\section{Sample collection}

Standard laboratory quality procedures were adhered to in all aspect of the study.

Sterile universal bottles were issued to each subject for the collection of clean catch mid-stream urine specimens. Clean catch early morning mid-stream urine for microbiological examination was collected from subject of the elderly population (from 60 years and above). The need to collect the urine with as little contamination as possible was explained to the subjects. Female patients were told to cleanse the area around the urethral opening with clean water, dry the area and collect the urine with the labia held apart. Male patients were told to wash the hands before collecting a specimen. They was told to allow the first part of urine pass out into toilet, then stop the urine flow and position the container and collect the mid-stream portion of the urine, then finish urinating into the toilet. The container was labeled with date, name, sex and age.

\section{Processing of urine samples}

Every urine specimen was cultured onto CLED and blood agar (BA) media applying Lee and Williams technique. ${ }^{8} \mathrm{Gram}$ staining technique and quality assessment biochemical were applied to identify the bacterial organism on the differential material. The media applied comprised meal corn, serum and agar sabouraud for isolation of Candidaalbicans. Staphylococcus aureus was identified by applying coagulase and catalase assessment techniques after culturing on salt mannitol as explained by Stokes. ${ }^{9}$ Escherichiacoli were identified by applying indole in water peptone and iron Kliglers agar substances as explained by Cruickshank et al. ${ }^{10}$ 
The Bauer-Kirby method assessment apparatus was applied for against microbe assessment of the isolates. ${ }^{11}$ Substances displaying important urine microbe of $10^{5} \mathrm{CFU} / \mu$ l were placed into water peptone to fit $0.5 \mathrm{McF}$ arland turbidity quality $\left(1.5 \times 10^{8}\right.$ bacteria $\left./ \mathrm{ml}\right)$ previous diffusing coating on Agar Hinton Muller. Open equipped against microbial discs of recognized least stoppage amounts were put on the area of the perceived agar enough and placed down with sterile forceps to enable touch with the substance. The materials were placed at $37^{\circ} \mathrm{C}$ for 24 hours and the section of development stoppage assessed. Thus perceived to a specific antibiotic was assessed if the extent of its area of stoppage by a drug was maximum than, fair to, or absence additional than $4 \mathrm{~mm}$ small than that on the normal culture. ${ }^{10}$ The subsequent against microbial perceived plate were applied; Augmentin $(30 \mu \mathrm{g})$, Gentamacin $(10 \mu \mathrm{g})$, Refloxacillin $(10 \mu \mathrm{g})$, Sparfloxacin $(10 \mu \mathrm{g})$ Ciprofloxacin $(10 \mu \mathrm{g})$, Chloramphenicol $(30 \mu \mathrm{g})$, Amoxacillin $(30 \mu \mathrm{g})$ Streptomycin $(30 \mu \mathrm{g})$, Septrin $(30 \mu \mathrm{g})$

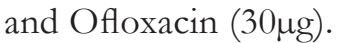

\section{Data analysis}

Statistical analysis was performed using a commercial statistical package: SPSS version 16.0 for windows and Microsoft Excel Tool Pak (SPSS for Windows: SPSS Benedeux, Gorinchem, Netherlands). The Chi-squared $\left(\mathrm{X}^{2}\right)$ test was used to test the variables according to age and gender. P-values $<0.05$ were considered significant while $\mathrm{P}>0.05$ were considered not significant.

\section{RESULTS}

A total of 150 samples were collected from randomly selected menopausal women in Calabar metropolis. This comprised of 150 test group (50 pre-menopausal, 50 menopausal, and 50 post-menopausal women) and also 50 young ladies of menstruating age (control group). Of the 150 test subjects examined, $24(16 \%)$ subjects were infected, while only $3(6 \%)$ of the 50 control subjects were infected. This was statistically significant $\left(\mathrm{X}^{2}=\right.$ $9.750 \mathrm{df}$ (2) $\mathrm{P}=0.008$. Table 1 shows, the distribution of infections according to age groups of subjects examined. Subjects aged 35-40 years had the highest prevalence of infection $6(18.5 \%)$, while age group 66-70yrs had the lowest infection rate $0(0 \%)$. There was no statistically significant difference in the prevalence of infection according to age group $\left(\mathrm{X}^{2}=1.417 \mathrm{df}\right.$ (4) $\mathrm{P}=0.841$. Table 2 shows the prevalence of asymptomatic bacteriuria among the study subjects according to status of menopause. Post-menopausal women had the highest prevalence of asymptomatic bacteriuria 10(20\%) while pre-menopausal and menopausal women had a lower prevalence rate of $7(14 \%)$ each. There was no statistically significant difference in the prevalence of infection according to status of menopause $\left(\mathrm{X}^{2}=0.750 \mathrm{df}(2) \mathrm{P}=0.687\right.$.

Table 3 shows theprevalence of asymptomatic bacteriuria according to other health abnormalities of subjects examined. Subjects who were diabetic had a higher prevalence rate $20 \%$ than those without diabetes $(14.5 \%)$. This was not statistically significant $\left(\mathrm{X}^{2}=2.667 \mathrm{df}\right.$ (1) $\mathrm{P}=$ 0.102.Subjects with previous history of UTI had a higher prevalence rate $(28.6 \%)$ than those with no previous history of UTI $(12.7 \%)$. This was not statistically significant $\left(\mathrm{X}^{2}\right.$ $=0.667 \mathrm{df}$ (1) $\mathrm{P}=0.414$.Subjects who were hypertensive had a higher prevalence rate $(16.7 \%)$ than those without hypertension $(15.6 \%)$. This was not statistically significant $\left(\mathrm{X}^{2}=4.000 \mathrm{df}(1) \mathrm{P}=0.549\right.$.

Figure 1. shows the frequency of occurrence microbes isolated. The organism with highest frequency of occurrence was Staphylococcus aureus (33\%) while Klebsiella spp. $(9 \%)$ was the organism with lowest frequency of occurrence. Figure 2. shows the antibiotic sensitivity pattern to commonly used antibiotics which includes Ciprofloxacin (100\%), Peflixacin (92.3\%) Chloramphenicol

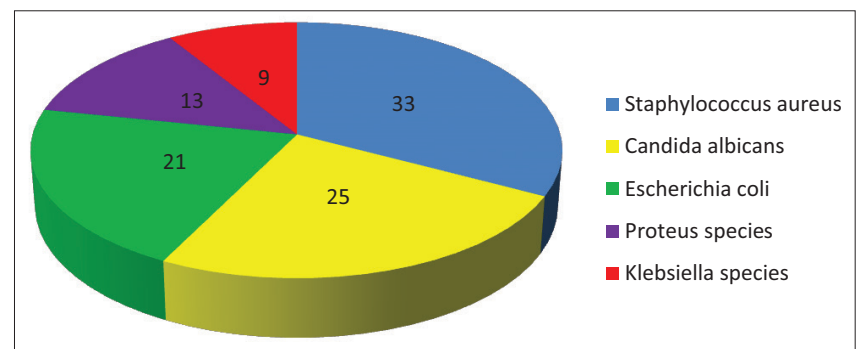

Figure 1: The frequency of occurrence microbes isolated

Table 1: Prevalence of asymptomatic bacteriuria among subjects examined

\begin{tabular}{|c|c|c|c|c|c|}
\hline \multicolumn{3}{|c|}{ Test subjects } & \multicolumn{3}{|c|}{ Control subjects } \\
\hline Age group (yrs) & No examined & No. (\%) infected & Age group (yrs) & No examined & No. $(\%)$ infected \\
\hline $41-45$ & 32 & $6(18.5)$ & $15-18$ & 13 & $1(7.6)$ \\
\hline $46-50$ & 34 & $6(17.6)$ & $19-22$ & 12 & $0(0)$ \\
\hline $51-55$ & 20 & $3(15)$ & $23-26$ & 10 & $2(20)$ \\
\hline $56-60$ & 30 & $4(13.3)$ & $27-30$ & 12 & $0(0)$ \\
\hline $61-66$ & 30 & $5(16.6)$ & $31-34$ & 3 & $0(0)$ \\
\hline $66-70$ & 4 & 0 & & & \\
\hline Total & 150 & $24(16)$ & & 50 & $3(6)$ \\
\hline
\end{tabular}




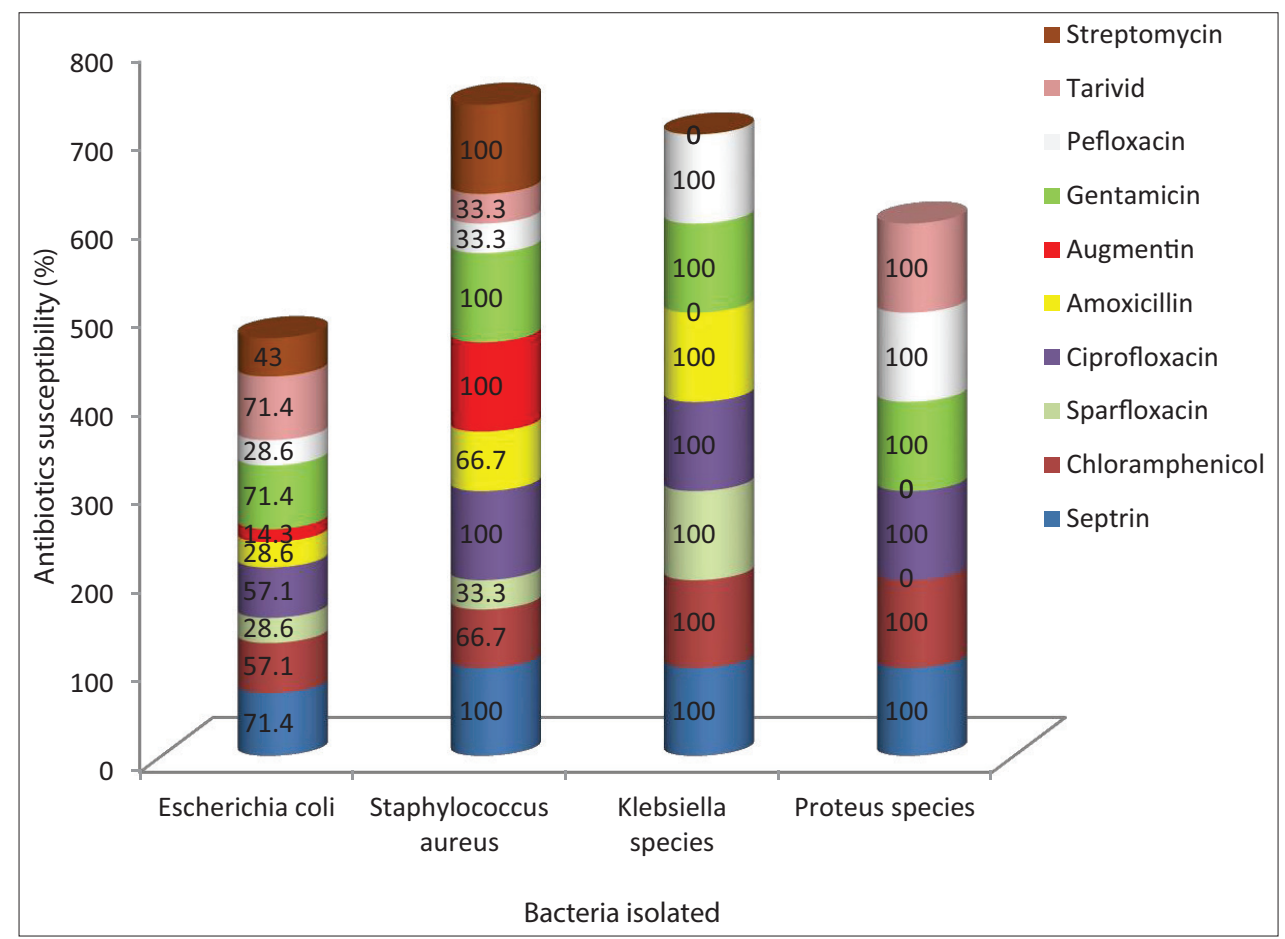

Figure 2: The antibiotic sensitivity pattern to commonly used antibiotics

\begin{tabular}{lcc}
$\begin{array}{l}\text { Table 2: Prevalence of asymptomatic bacteriuria } \\
\text { according to status of menopause of subjects } \\
\text { examined }\end{array}$ \\
\hline Status & No. Examined & No. (\%) Infected \\
\hline Premenopausal & 50 & $7(14)$ \\
Menopausal & 50 & $7(14)$ \\
Post-menopausal & 50 & $10(20)$ \\
Total & 150 & $24(16)$ \\
\hline
\end{tabular}

\begin{tabular}{lcc}
$\begin{array}{l}\text { Table 3: Prevalence of asymptomatic bacteriuria } \\
\text { according to other health abnormalities }\end{array}$ \\
$\begin{array}{l}\text { of subjects examined } \\
\text { Health } \\
\text { abnormalities }\end{array}$ & $\begin{array}{c}\text { No. } \\
\text { Examined }\end{array}$ & No. (\%) with infection \\
\hline Diabetic & 40 & $8(20)$ \\
Non diabetic & 110 & $16(14.5)$ \\
$\begin{array}{l}\text { Previous history } \\
\text { of UTI }\end{array}$ & 35 & $10(28.6)$ \\
No previous history & 115 & $14(12.17)$ \\
of UTI & & $10(16.7)$ \\
Hypertensive & 60 & $14(15.6)$ \\
Non hypertensive & 90 & $24(16)$ \\
Total & 150 & \\
\hline
\end{tabular}

$(90 \%)$, Gentamicin $(84.6 \%)$ and Septrin $(80 \%)$ in each of the test isolates used.

\section{DISCUSSION}

Bacteriuriais common among women of all ages with a lifetime risk of up to $60 \%{ }^{3}$ This is depicted in the result of the 150 test subjects examined which $24(16 \%)$ subjects had infection, while only $3(6 \%)$ of the 50 control subjects were infected and this was statistically significant $(\mathrm{P}=0.008)$. The $24 \%$ prevalence of asymptomatic bacteriuria observed in this study among the test subjects is higher than that of Vorland et al., ${ }^{12}$ who reported $4 \%$ in an epidemiological survey in northern Norway and that reported in Australia by Mulder et al., ${ }^{13}$ who had $11.2 \%$ prevalence of asymptomatic bacteriuria among menopausal women but lower than that of Jolleys, ${ }^{14}$ who reported a prevalence of15\%in England.

Subjects aged 35-40 years had the highest prevalence of infection (18.5\%), while age group 66-70yrs had the lowest infection rate $(0 \%)(\mathrm{P}=0.841)$. This is contrary to the report by Kasyan et al., ${ }^{15}$ who reported that bacteriuria increased with age in women,even though the authors stressed that the condition is associated with the growth of important dead alteration of the lining vaginal and urethra in the after menarche time with estrogen lack and alteration of the microbe vaginal.

The study also observed $20 \%$ prevalence of asymptomatic bacteriuria among post-menopausal group (Table 2). This is lower than that observed in a study carried out in Korea by Raul Roz et al., ${ }^{16}$ which revealed $23.4 \%$ prevalence of asymptomatic bacteriuria among post-menopausal women.

Subjects with previous history of UTI had a higher prevalence $(28.6 \%)$ than those with no previous history of UTI $(12.17 \%)$. This further confirms the fact that

Asian Journal of Medical Sciences | Jul-Aug 2018 | Vol 9 | Issue 4 
urological factors like previous urinary tract infection contribute to the high prevalence in this population.

Asymptomatic bacteriuria in postmenopausal women with diabetes has been reported as a risk factor for development of symptomatic UTI. Bacteriuria has been reported as one of the major non-specific complications in diabetic patients is the urinary tract infection. ${ }^{16}$ Subjects with history of diabetes had a higher prevalence $(20 \%)$ than those with no history of diabetes (14.5\%).This is in consonance with the report by certain writers that the number of urinary canal contamination in sufferers with diabetes can rise up to attain $40 \%$, which is over three periods maximum than in the universal number Kasinath et al. ${ }^{17}$ Urinary canal contamination likely compound the line of diabetes and associate the disease with a maximum danger of quick decayed of renal role, particularly in sufferers with medical indicators of nephropathy diabetic and artery excess force. And in this work subjects with history of hypertension had a higher prevalence $(16.7 \%)$ than those with no history of hypertension $(15.6 \%)$.

However, despite the high mundane of bacteriuria in post-menopausal women (young and institutionalized), majority of urinary tract infection (UTI) studies has been carried in younger women. Hence, the most common urinary tract infection risk factors among healthy younger women, such as frequent vaginal intercourse, spermicide use, diaphragm use, condom use, a previous urinary tract infection history, recent antibiotic and non secretor status were not widely investigated in middle aged and elderly women.

Staphylococcus aureus had the highest occurrence of 33\%, followed by Candida albicans 25\%, Escherichia coli 21\%, Proteus spp 13\% and Klebsiellaspphad the least occurrence of $9 \%$. The risk of urinary tract infection can be reduce among the menopausal, post-menopausal and younger adults by maintaining a high personal hygiene and reduce sexual activities which expose the individuals to the infection.

\section{CONCLUSION}

The prevalence of asymptomatic bacteriuria among menopausal women in Calabar is $24 \%$. The highest incidence of asymptomatic bacteriuria in menopausal women and they were generally susceptible to Ciprofloxacin, Pefloxaxin, Chloramphenicol, Gentamicin and Septrin seven though susceptibility to these Antibiotics varies with the organism.

\section{ACKNOWLEDGEMENT}

Management and staff of Incopa Medical Laboratories, Calabar.

\section{REFERENCES}

1. Mody $L$ andJuthani-Mehta $M$. Urinary tract infections in older women: a clinical review. JAMA 2014; 311(8):844-854.

2. Milart P. Woźniak S. Czuczwar P. Szkodziak P. Paszkowski T. Woźniakowska E. et al. Urinary tract infections in the menopausal period: Optimal management. Menopausal Review 2013; 1(1):23-28.

3. Foxman B. Urinary tract infection in postmenopausal women. Current Infectious Disease Reports1999; 1(4) 367-370.

4. Forland $\mathrm{M}$, Thomas $\mathrm{V}$ andShelokov $\mathrm{A}$. Urinary tract infections in patients with diabetes mellitus. Studies on antibody coating of bacteria. JAMA 1977;238:1924.

5. Harding I, Godfrey KM, Zhanel E, George G, Nicolle LE and Chang M. The Manitoba diabetes urinary tract infection study group antimicrobial treatment in diabetic women with asymptomatic bacteriuria. New Engl J Med 2002; 347: 1576-1583.

6. Raz R. Urinary Tract Infection in Postmenopausal Women. Korean J Urol 2011; 52(12):801-808.

7. Ottong JG, Ering SO andAkpan, FU. The Population Situation in Cross River State of Nigeria and Its Implication for SocioEconomic Development: Observations from the 1991 and 2006 Censuses (PDF). Journal of Emerging Trends in Educational Research and Policy Studies 2010; Retrieved 2018-09-08.

8. Leigh DA and Williams JD. Method for the detection of significant bacteriuria. J ClinPathol 1964; 17: 498-503.

9. Stokes EJ. Clinical bacteriology. Fourth edition, Edward Arnold (publishers Ltd) London. 1975; 109-202.

10. Cruickshank R, Duguid JP, Marmion BP, Swain RHA. Medical Microbiology $12^{\text {th }}$ Edition Volume Two: The practice of Medical Microbiology 200p. Churchill Livingstone Edinburgh London and New York.1975; 427-429.

11. Bauer AW, Kirby WM, Sherris JC andTurck M. Antibiotic susceptibility testing by a standardized single disk method.Am J ClinPathol 1966; 45: 493-496.

12. Vorland LH, Carlson $\mathrm{K}$ and Aalen $\mathrm{O}$. An epidemiological survey of urinary tract infections among outpatients in Northern Norway. Scand J Infect Dis 1985; 17: 277-283.

13. MulderTanddeReusR.Psychiatric IllnessdoesnotProtectAgainst a Somatic Disease.Nederlandstijdschriftvoorgeneeskunde 2001; 145 (28):1333-1336.

14. Jolleys JV. Factors associated with regular episodes of dysuria among women in one rural general practice. Br J Gen Pract 1991;41(347):241-243.

15. KasyanG,BerketovaTY, Rogozin AK and Pushkar DY. Asymptomatic bacteriuria in postmenopausal women with diabetes mellitus. Cent European J Urol 2013; 66(3): 320-326.

16. Geerlings SE, Stolk RP, Camps MJL, Netten PM, Hoekstra JBL andBouter KP. Prevalence and risk factors for asymptomatic bacteriuria in women with diabetes mellitus. ICAAC 1999 abs 607

17. Kasinath BS, Musais SK, Spargo BH and Katz Al. Nondiabetic renal disease in patients with diabetes mellitus. Am J Med1983;75:613-617. 
Authors Contribution:

PCl-Concept and design of the study, collection of data; manuscript preparation, preparation of manuscript draft; AUA-Concept and design of the study,

collection of data; manuscript preparation, preparing of manuscript draft; VOU-reviewed the literature, collected data; statistically analyzed and interpret data, preparing of manuscript draft; GCE- reviewed the literature, collection of data; statistically analyzed and data interpretation, preparing first draft of manuscript.

Orcid ID:

Dr Paul Inyang-Etoh - (1D https://orcid.org/0000-0001-5541-6829

Source of Support: Nil, Conflict of Interest: None declared. 